\title{
Chapter 11 \\ Securitization, Emergency and the Rediscovery of Responsibility in Times of Pandemic: Analyzing Political Discourses from the European South
}

\section{Salomi Boukala and Dimitris Serafis}

\begin{abstract}
This chapter intends to provide an argumentative perspective on the justification of securitization by Southern EU's political leaders in times of a public health crisis and the COVID-19 pandemic by examining instances of public discourses, specifically addresses to the nation of four EU leaders with different ideological positioning, in different social settings of the European South. Based on the theory of securitization, we perceive public debate as a polylogical phenomenon where multiple actors, from multiple (ideological) positions, in multiple times and spaces interact, creating a complex network of public communication while expressing and supporting their claims. Through this prism, our aim is to shed light on argumentative polylogues by unveiling whether and how the state of emergency has been justified. We employ the frame of the Discourse-Historical Approach (DHA) to Critical Discourse Studies (CDS) (Reisigl \& Wodak, 2016) to study the socio-historically conditions against which established endoxical premises are (re)constructed by the political leadership and how these interrelate with specific argumentation strategies (topoi) in the social settings under scrutiny. We then draw on the quasi-Y structure provided by the Argumentum Model of Topics (AMT) (Rigotti \& Greco, 2019) to scrutinize the interplay of topical and endoxical premises in the development of single standpoint-argument couplings.
\end{abstract}

Keywords Securitization $\cdot$ COVID-19 pandemic $\cdot$ Political discourse $\cdot$ Southern EU $\cdot$ Argumentative polylogues $\cdot$ Discourse-Historical Approach $\cdot$ Critical Discourse Studies • Argumentum Model of Topics

\footnotetext{
S. Boukala $(\bowtie)$

Department of Social Anthropology, Panteion University of Social and Political Sciences, Athens, Greece

e-mail: salomi.boukala@panteion.gr

D. Serafis

Institute of Linguistics and Language Technology, University of Malta, Msida, Malta

e-mail: serafisdimitris@gmail.com
}

S. Oswald et al. (eds.), The Pandemic of Argumentation, Argumentation Library 43,

https://doi.org/10.1007/978-3-030-91017-4_11 


\subsection{Introduction}

The COVID-19 pandemic has unprecedently modified the social and living conditions in Europe. The videos depicting the overloaded intensive care units in Italy and Spain that were affected hard by the first wave of coronavirus were among the exemplary instances that accelerated insecurity and fear at the beginning of the public health crisis in March 2020. As such, the COVID-19 pandemic added to a continuum of multiple and long-standing crises in Europe such as the debt crisis (e.g. Kelsey et al., 2016; Serafis \& Herman, 2018) and the 'refugee crisis' (Krzyżanowski et al., 2018). As Wodak noted "[e]ach crisis contributes to both new and old threat scenarios" and, as evidenced in the context of the ongoing pandemic, COVID-19 was "instrumentalized by governments in various ways in order to persuade people to comply with restrictive measures in view of the pandemic" (Wodak in press and refs therein). Through this prism, our aim here is to examine the discursive construction of the pandemic threat and how it links to the security measures that were implied to mitigate the spread of COVID-19. In particular, this chapter aims to offer an argumentative perspective to the justification of securitization by Southern EU's political leaders in times of a public health crisis and the COVID-19 pandemic; the argumentative justification of securitization that, in so far as to our knowledge, remains rather overlooked.

In the following, we first outline a theoretical discussion that frames the ways political leaderships' public discourses on COVID-19 pandemic, in different contexts (Greece, Italy, France and Spain) and from different political perspectives (right wing, centrism and left wing), converge to the imposition of measures in the fight against the pandemic, based on the theory of securitization; securitization refers to the discursive construction of an event as a threat, implicitly suggesting countermeasures to address this very threat (see McDonald, 2008). We grant the premise that public discourses and argumentation "in contemporary controversies and deliberation involves many players, many positions, and many places" and, as such, it is "the many-to-many polylogue that requires further conceptualization for argumentation theory" (Aakhus \& Lewiński, 2017: 179, original emphasis). Moreover, given the fact, as Wodak (in press) maintains, that authoritarian tendencies are established in the relevant pandemic, we claim that argumentative polylogues in times of COVID 19 crisis should be seen from a critical perspective. Specifically, we draw on the framework of Critical Discourse Studies (henceforth CDS) (see Wodak \& Meyer, 2016) to show how social inequalities and authoritarian turns can be sustained in the respective argumentative polylogues. Within this framework, we firstly employ analytical tools from the Discourse-Historical Approach (henceforth DHA) to CDS to study "nomination-", "predication-" and "argumentation strategies" (see Reisigl \& Wodak, 2016) to illustrate the authoritative dimension of the public health and social measures that were developed on the basis of security and public safety. Then, we pay particular attention to the ways in which argumentation strategies (i.e. topoi in DHA terms) interrelate with dominantly accepted macro-values, namely endoxa (see Boukala, 2016). We scrutinize the topoi-endoxa (inter)relation by appealing to the 
quasi-Y reconstruction provided by the Argumentum Model of Topics (henceforth AMT) (see Rigotti \& Greco, 2019) that enables as to show how standpoint-argument couplings are developed through inferences that stem on the basis of topoi (or loci in AMT terms) and endoxa. To explicate our methodological framework, we focus on a specific "discourse strand" (Rheindorf, 2019: 210-211) regarding COVID-19 at the beginning of the respective pandemic, that is in mid-March 2020, and we examine instances of public discourses, specifically addresses to the nation of four EU leaders (Kyriakos Mitsotakis, Giuseppe Conte, Emanuel Macron, Pedro Sanchez) with different ideological positioning, in different social settings of the European South. It becomes a truism nowadays that the social settings under study have gone through a long-standing polarization since 2010, being affected by the turbulences of the Eurozone debt crisis, the refugee crisis, among others (see e.g. Kelsey et al., 2016; Krzyżanowski et al., 2018). This very fact permits us to see the countries under study together as part of the same context for the sake of this analysis. In light of the analysis, we sketch a discussion and some tentative conclusions.

\subsection{Securitization and the Discursive Construction of the Enemy in Times of Crisis}

The discursive construction of specific topics and contexts as threats and the necessity for security has been well examined along the lines of the concept of securitization by the so-called Copenhagen School approach, among others, in cases such as "immigration, health, political dissidence and minority rights" (McDonald, 2008: 563). The concept was initially informed by Austin's (1962) theory of speech acts and, accordingly, in this frame:

securitization can be defined as the positioning through speech acts (usually by a political leader) of a particular issue as a threat to survival, which in turn (with the consent of the relevant constituency) enables emergency measures and the suspension of 'normal politics' in dealing with that issue (McDonald, 2008: 567).

Hence, the theory of securitization is based on the discursive construction of a threat that leads to the legitimation of decision-making that could challenge civil rights in the name of national security. Moreover, recent approaches of the relevant concept, moved beyond the verbal means by which a securitization perspective could be realized. In particular, scholars within the same framework, considering the $9 / 11$ attacks in the US, pinpointed the role of visual recourses (e.g. images) and other multimodal representations to be core elements in the discursive construction of security in times of crises, when certain issues are portrayed as threats that need to be addressed at any cost (see Williams, 2003; Möller, 2007). All in all, the core logic of this perspective is that the discursive construction of "threats justifies the use of extraordinary measures to handle them" (Buzan, Wæver \& de Wilde, 1998: 21). Furthermore, the threat (existing or imaginary) could lead to the reinforcement of specific political elites. 
According to Williams (2003: 514) security is one of the main means that is used by political elites to represent an existing -or not threat which might call for extraordinary measures beyond the prism of everyday politics. A state of emergency or, as Agamben (2003) labelled it, state of exception, "which appears as a threshold of indeterminacy between democracy and absolutism" (Agamben, 2003: 3). We argue that the emergency decrees announced by the political figures under investigation promoted security and the legitimation of emergency in the name of people's safety against COVID-19. Through these premises, in what follows, we provide a theoretical discussion on the ways public argumentation in polarized times of crises could be conceived as a polylogical network that occurs at the interplay of different actors, in different places and times who apparently have different objectives.

\subsection{Argumentative Polylogues and Standing Standpoint in Times of Pandemic}

If crises are the highly fluid and polarized socio-political terrains where pre-existing values and views are (re)negotiated (Stråth \& Wodak, 2009) through the innumerable perspectives that circulate in the public sphere, then within these contexts, a complex network of public communication may be constructed on the basis of interconnected public controversies and positions. In fact, as Fairclough and Fairclough (2012) pinpoint, crises are the contexts within which numerous, and, most of the times, contradictory open questions determine the public debate. Hence, we argue that discourses on crises could constitute an effective terrain for the public acceptance of restrictive measures that are developed on the basis of a serious threat and in the name of public security. In other words, the numerous political answers-positions coming from different actors in power, in different socio-temporal spaces, should point toward a mosaic of perspectives that could enable societies to overcome the crisis. It is on that basis that crises can be seen as the terrains where argumentative polylogues (see e.g. Lewiński \& Aakhus, 2014; Aakhus \& Lewiński, 2017) can be evolved.

As Aakhus and Lewiński (2017) put it,

[an] argumentative polylogue [is defined] not simply as a discussion between multiple participants, but rather multiple different argumentative parties defending their distinct positions. [The underlying premise is that] public controversies are dynamic activities where multiple parties pursue multitude of positions that unfold over time in a variety of places (2017: 181-182; original emphasis).

Through this prism, the positions expressed by leaders with different political and ideological backgrounds through their messages to the peoples of different European member-states at the very beginning of the COVID-19 pandemic, could be described in terms of an argumentative polylogue. More specifically, as we will further witness in our analysis, while the EU leaders kick off the relevant debate 
from different ideological starting points, namely a center-right (Kyriakos Mitsotakis, Greece), a centrist-populist (Giuseppe Conte, Italy), a centrist-liberal (Emanuel Macron, France) and a center-left (Pedro Sánchez, Spain), they all appear to argue for the necessity of the restrictive measures to address the pandemic in the different EU contexts. While doing so, among other things, they employ the notion of invisible enemy and a construction of pandemic-as-war, further enforcing a discursive construction of a dangerous threat that needs to be fought in the name of public security and safety and is linked to a securitization perspective in the European public sphere through the prism of the COVID-19. In this sense, their discursive constructions tend to converge, naturalize an authoritarian tendency on the basis of restrictive measures. To explain this convergence in theoretical terms, we appeal to the notion of standing standpoint (Mohammed, 2019).

In Mohammed's (2019) words,

[a] standpoint that is attributed to an arguer on the basis of an argument that has become publicly associated with the standpoint may be referred to as a standing standpoint.[I]t takes effect only once a certain context is in place [, it is] always implicit [and] [i]n that sense, [it] $\mathrm{ha}[\mathrm{s}]$ something of an enthymeme where the conclusion is unexpressed (2019: 318-319).

As such, a standing standpoint always remains implicit, and can be legitimately inferred as the final claim implicitly sustained by all different actors on the basis of their individual claims. In the present case, we could plausibly interpret the standing standpoint as being the consensus point or the agreement built among the different EU political leaders at the beginning of the pandemic. It is on this basis that authoritarian tendencies might be ultimately normalized. In other words, employing the discussion regarding the background knowledge on the ways securitization is explicated through the prism of the discursive construction of a threat (see Sect. 11.2), we argue that political leaders are associated to standing standpoints, recontextualizing and justifying — through the underlying argumentation — their political decisions in times of pandemic.

To provide a critical micro-analysis of the reasoning based on which the aforementioned polylogue and, ultimately, the standing standpoint are premised, next, we present a synthesis of principles and tools coming from the Discourse-Historical Approach (DHA) to CDS (see Reisigl \& Wodak, 2016) and the Argumentum Model of Topics (AMT) (see Rigotti \& Greco, 2019).

\subsection{Scrutinizing Argumentative Polylogues: A DHA-AMT Micro-level Synthesis}

Focusing on the micro-level of our analysis, that is the examination of discursive constructions in public texts by the EU leaders during the time span under examination, we firstly employ principles and tools from the DHA to CDS. This approach permits us to unveil the discursive constructions in the different speeches, based on two main strategies. Namely, (a) the "nomination strategies" which refer to the 
"discursive construction of social actors, objects, phenomena, events, processes and actions" in terms of "metaphors, metonymies [and/or] verbs and nouns used to denote processes and actions" and (b) the "predication strategies" which include "the discursive qualification of social actors, objects, phenomena, events, processes and actions (positively or negatively)" realized, among others, by "(stereotypical) evaluative attributions of negative or positive trails [...], explicit predicates or predicative nouns/adjectives/pronouns" (see Reisigl \& Wodak, 2016: 33). Based on this first layer of micro-analysis, we then move toward an examination of the argumentativity (Reisigl \& Wodak, 2016: 27; see also Amossy, 2009a, 2009b; Herman \& Serafis, 2019) that permeates the aforementioned discursive constructions. This can be unraveled in terms of the "argumentation strategies" that adumbrate the basis of the "justification and questioning of claims of truth and normative rightness" through the use of topoi (see Reisigl \& Wodak, 2016: 33). More specifically, DHA scholars perceive topoi as being some kind of "content-related warrants or 'conclusion rules' which connect the argument(s) with the conclusion, the claim [...], justify[ing] the transition from the argument(s) to the conclusion [realized in terms of] conditional or causal paraphrases such as 'if $x$, then y' or 'y, because x"' (Reisigl \& Wodak, 2016: 35; see also Reisigl \& Wodak, 2001: 75-80; Reisigl, 2014). Drawing upon the topoi tradition, we argue that topoi are the logical basis on which a claim can be developed. Moreover, Boukala $(2016,2019)$ argues that topos should be methodologically seen as interrelating with accepted knowledge in contexts; this last is conceived in terms of the Aristotelian concept of endoxon (plural: endoxa) (see also Amossy, 2002). As such, topoi and endoxa are the starting premises from which something is claimed in an argumentative situation and we focus on them to decode the EU leaders argumentation on the necessity of restrictions and other government measures.

In an attempt to emphasise the analysis of particular standpoint-arguments borne out in EU leaders' discursive constructions on security and threat, we draw on the quasi-Y reconstruction given by the AMT that provide an effective mean for our analysis. Based on the same conceptual ground as the DHA, the AMT examines how argumentative inferences are developed on the basis of topical and endoxical premises (see Serafis et al., 2020, Serafis et al. in press; for integrations of the AMT under a CDS perspective). More specifically, the AMT, outlines two different components that, if cross-examined, can show us the inferential connection between a standpoint and the supporting argument(s) (see Rigotti \& Greco, 2019: 208-216, for an overview). The first one (i.e. the so-called "procedural inferential component") comprises the "locus" (topos in Latin), that is the (onto)logical relation from which the argumentative inference departs, and the "maxim", which refers to the various inferential principle(s) that are connected with each locus. The analytical advantage of this distinction between loci and maxims is that it "allows the list of topoi to remain within a reasonable number, while allowing for as many maxims as the analysts discover during the analysis of real texts" (Serafis et al., 2020: 560; based on Rigotti \& Greco, 2019: 74). To provide a clear example here, in a "cause-effect" relation one of the maxims could be: "if the cause is present so does the effect" (see Rigotti \& Greco, 2019: 208-209). The second component (i.e. the "material contextual" one) refers to the "endoxon", that is the dominant views in a particular 
context and the "datum", which is actually the outcome from the interpretation of the discursive construction of the text (see Rigotti \& Greco, 2019: 214-215); in our case the DHA analysis of nomination and predication strategies, could help us unveil the datum in each case and realize how the EU leaders develop their rhetoric under the umbrella of securitization. It is in this sense, that AMT may be advanced by the discursive strategies that the DHA pinpoints. At the intersection of the aforementioned components, we can step-by-step reach the "final conclusion" specifically the EU political decisions on COVID 19, which represents the defended claim.

As evident, DHA and AMT conceive in similar ways how argumentative moves may be developed in public texts. As Serafis et al., explain: "[T]he novelty that the AMT brings into th[is] picture is a rigorous examination of the ways in which topical and endoxical premises interrelate in the defense of a standpoint" (Serafis et al. in press). To do so, AMT could draw on an in-depth analysis of the discursive strategies (i.e. nomination and predication strategies) that could explicate the factual premises (i.e. datum) of the material component in each single argumentation. On this methodological basis, next we zoom in on our data.

\subsection{Data Analysis and Discussion}

We have chosen to focus on the discourses produced in addresses to the nation by the leaders of Southern EU member-states due to the central role that the European South played in multiple crises (debt, political, refugee, health). As already mentioned, since 2010, European South suffered by austerity policies during the Eurozone debt crisis, witnessing a structural transformation of its political system; this was also accompanied by the 2015 refugee crisis. In the Southern European context, our focus was on political leaders that serve governments with different ideological backgrounds. Namely, a center-right (Greece), center-populist (Italy), centrist (France) and center-left (Spain) orientation. In consequence, we deal with political actors with apparently different political starting points and objectives in the different social settings from whom, we can legitimately maintain, polylogical argumentative moves may depart. Our aim is to examine the similarity or differences of their arguments on the security of their nations and the fight against the pandemic threat.

Our study focused on a specific "discourse strand" at the beginning of the so-called 'first wave' of the COVID-19 pandemic (mid-March 2020). According to Rheindorf (2019: 283), a discourse strand is a set of data defined "in terms of an initiating event, topical continuity, strong intertextual links, and a limited group of social actors". In our case, the examined data are produced by an elite group of powerful social actors, namely the Southern EU political leaders, in response to the COVID-19 eruption. Moreover, as we will show, the texts under analysis, released in this short time span (i.e. March 2020), are characterized by strong intertextual linkages (see Kristeva, 1980; Fairclough, 2003: Ch. 3) through, for instance, explicit references to the '(invisible) enemy' and the role of the 'State' in the fight against it, anchoring in this sense 
dominant meaningful constructions in different social contexts through their multiple recontextualizations (Wodak \& Fairclough, 2010). In this sense, we can confidently maintain that the discourse strand under analysis provides us with a coherent snapshot of the political discourse on the relevant topic in the period under scrutiny. More importantly, although we deal with a polylogical argumentative network, as described above, we will witness that the different texts end up converging, producing solid discursive constructions that justify a securitization perspective and legitimation of the state of exception through the embedded argumentation and, more specifically, the emerging standing standpoint. Details regarding the speeches under examination (i.e. where, how long they were and what topics they covered etc.) are given in the links provided. For reasons of space we will refer to the most important details throughout our analysis. Next, we move to the data analysis.

On March 16th 2020, Emanuel Macron, President of the French Republic addressed his nation to announce a national lockdown, as hospitalizations were increased across the country. ${ }^{1}$ In particular, he mentioned:

(1) Women and men of France, On Thursday night I spoke to you about the health crisis that our country is confronting. Until that point, for some of you the epidemic might be a distant notion; however, it has become an immediate and pressing reality for our country as well [...] The government has taken strong measures to slow the spread of the virus [...] France has never had to make such decisions, which are, of course, exceptional and temporary in peacetime. They were taken in an orderly, prepared way, based on scientific recommendations and with one sole objective: to protect us from the spread of the virus. ${ }^{2}$

Macron explicates to the French people that the virus is not 'a distant notion', quite the contrary it has attacked the country and led to a health crisis ("immediate and pressing reality for our country'). He justified the decision to limit free movement as a necessary measure to 'protect the nation from the virus' and amplified the validity of that decision by referring to 'scientific recommendations'. In this sense, he appears as the responsible force that based on the health authorities' recommendations, fulfils his presupposed role as the guardian of the society. An argument that is further developed via the Aristotelian topos of the analogue consequences (Rhetoric, B23, 1399b) or the DHA topos of responsibility (Reisigl \& Wodak, 2001: 78) that here can be identified as topos of governmental responsibility. This can be further paraphrased as "if the nation faces a health crisis, then the government has to utilize every means to protect the health and prosperity of the people".

In a similar vein, during his mandate to the Greek people on March $22,{ }^{3}$ the rightwing Greek Prime Minister Kyriakos Mitsotakis, appealed to 'the Constitution' of the Hellenic Republic to back up his decision for a general lockdown:

(2) My fellow citizens, [...] The State must, according to the Constitution, "ensure the health of its citizens" and to interfere when the exercise of the civil liberty

\footnotetext{
${ }^{1}$ See: https://www.youtube.com/watch?v=m_pXUmz5qN0.

${ }^{2}$ All the extracts have been translated into English by the authors.

${ }^{3}$ See: https://primeminister.gr/2020/03/22/23615.
} 
goes beyond the constitutional objectives and threatens the society. And when one's responsibility proves to be in deficit, then the public interest must be safeguarded. Thus, in the name of the common well I take today's decision.

As evident, Mitsotakis explains the responsibilities of the 'State' (i.e. 'The State must, "ensure the health of its citizens", '[The State must] interfere when the exercise of the civil liberty goes beyond the constitutional objectives and threatens the society'). As such, the PM appears to be fully compliant with the charter of the Greek society ('the Constitution') and Greeks 'common-well', and therefore his actions and decisions should be embraced by the society. Again, the topos of governmental responsibility supports his political decisions.

The same kind of argumentation was followed by the Spanish Prime Minister and Secretary General of the Spanish Socialist Party, Pedro Sanchez when he addressed the Spanish nation on March 13th 2020 to declare a state of alarm (state of emergency $)^{4}$ :

(3) Dear compatriots, Today, I have just communicated to the Head of State to declare the State of Alarm throughout our country, throughout Spain, for the next 15 days. The State of Alarm is an instrument of our Rule of Law, included in our Constitution, to face such extraordinary crises as the one that unfortunately the world and our country is suffering. The health and social emergency generated by the coronavirus known as COVID-19, creates extraordinary circumstances such as those contemplated by the Law to provide the Government of Spain with legal resources, also extraordinary.

Sanchez argues that COVID-19 is linked to 'extraordinary circumstances' that led to extraordinary political decisions, such as the declaration of the state of alarm. Hence, he underlines the importance of emergency decrees and the state of exception. By referring extensively to the Spanish Constitution (as his Greek counterpart did with the Greek constitution), PM attempted to justify such a difficult political decisionmaking. As he further, explained:

(4) These decisions will be aimed at mobilizing all the resources of the State as a whole to better protect the health of all citizens [...] The Government of Spain will protect all citizens and will guarantee adequate living conditions to stop the pandemic with the least possible impact [...] I understand the political importance of such a decision, but I believe that we shall fight against the enemy all united.

Sanchez accepted the political cost of the decision and explicated that it is important to proceed to the state of alarm as a weapon against the 'enemy', the existing threat of the pandemic. In the relevant predicates he represents his government and the Spanish authorities as a responsible group that can ensure the safety of the Spanish people ('to better protect the health of all citizens...', 'and will guarantee adequate living conditions to stop the pandemic with the least possible impact...'). As such, his argumentation in favor of the necessary restrictions is honed by employing the

\footnotetext{
${ }^{4}$ See: https://www.youtube.com/watch?v=dS-bLh9Fud4.
} 
topos of governmental responsibility. As also evident, he utilized a war metaphor to highlight the emergency and to stress the necessity for the Spaniards to be 'united' against the 'enemy'. We will further analyze this war metaphor choice below.

What is most important in the analysis of extracts $1-4$, is the leaders' attempt to secure their presupposed role to achieve their peoples' consent to the state of emergency/exception. Namely that of the responsible guardian of the constitution who acts in favor of the society. Their argumentation predominantly revolves around the topos of governmental responsibility, on the basis of which a plausible standpointargument pair could be: 1 State's action should be embraced by the general public 1.1. These actions are compliant with the Constitution and the role the State must have in securing the common-well. In AMT terms, the respective standpoint is facilitated on the basis of the locus from ontological implications (see Rigotti \& Greco, 2019: 254), which is exemplified in terms of a maxim: if $\mathrm{X}$ does something good $\mathrm{X}$ should be thanked/embraced. On the material-contextual component, the endoxon would be: the Constitution should be followed and the common-well should be secured, while the datum that emerges from the extracts is the following three-fold: The government has taken strong measures to slow the spread of the virus (extract 1), PM is compliant with the Constitution and aims to secure the common-well (extract 2), The State will protect the health of all citizens and will stop the pandemic (extract 4). At the intersection of maxim and datum the first conclusion could be: State authorities do something good, and thus the final conclusion is: State's actions should be embraced by the general public (see Fig. 11.1).

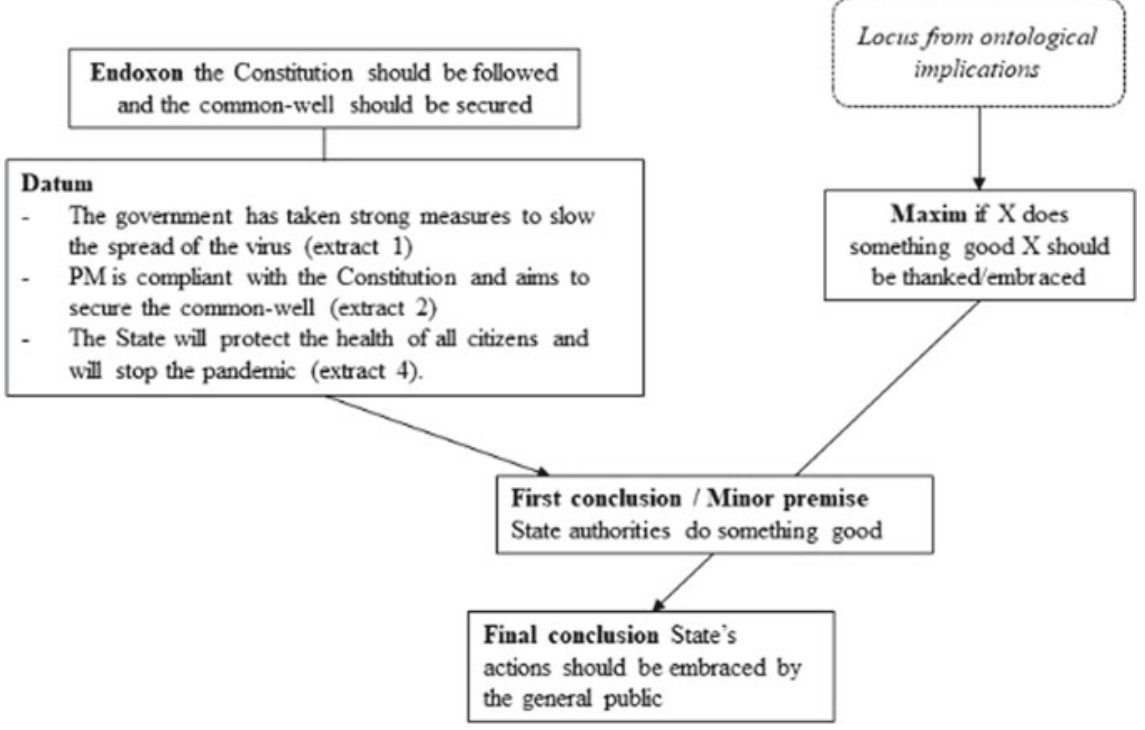

Fig. 11.1 The AMT quasi-Y reconstruction 
Zooming in on the war metaphor that previously emerged in Sanchez's speech ('we shall fight against the enemy all united'), this also dominated Macron's rhetoric. As he mentioned:

(5) We are at war, admittedly a health war: we're fighting neither an army nor another nation. But the enemy is there, invisible, elusive, and it's making headway. And that requires our widespread mobilization [...] We are at war. All the action of the Government and Parliament must now be geared toward combating the epidemic. Both day and night, nothing must divert us from this. We are at war. I call on all the political, economic, social and charity stakeholders and all French people to be part of this national unity that has enabled our country to overcome so many crises in the past.

Thus, the war metaphor has an important part in the political figures' discourses, insofar as it emphasizes the threat and ensures the consent of people to the restrict measures being imposed.

Furthermore, Sanchez focused on the impending dramatic consequences of the virus to support his argumentation:

(6) We are only in the first phase of a fight against a virus that attacked all the countries of the world and in particular our continent, Europe. We expect, as I said at the beginning of the week, very hard weeks. We said that difficult days would come and we have to take measures to fight the enemy as more than ten thousands Spaniards will be affected from it.

And, as Mitsotakis finally claimed on that concept on March $17^{5}$ :

(7) We are at war. Against an enemy that is invisible but not invincible. [...] The greatest weapon against COVID-19 is, still, our everyday behavior [...]. The government does its duty. But, believe me, the victory will come only if all of us - each one of us - prove to be disciplined soldiers in this "war for life". Because the enemy is invisible and devious

Here, we present characteristic extracts of speeches delivered by the three leaders to underline the usage of the war metaphor that is repeated along their addresses to the nation too many times, creating intertextual linkages and thus inductively binding a dense discursive construction. By employing this metaphor the relevant leaders emphasized the danger of the epidemic (thereafter pandemic), ${ }^{6}$ adopting a militaristic frame, commonly observed in political communication on COVID-19 (e.g. Castro Seixas, 2021), while explicitly targeting the 'enemy' against whom the 'war' is to be fought. Two social actors dominated the above extracts from the political figures, the epidemic/pandemic that is characterized as 'enemy-invisible and elusive' (Macron) 'invisible and devious' (Mitsotakis) and the national governments, authorities and elites that have a duty to protect people via the restrictive measures that have decided (Macron).

\footnotetext{
${ }^{5}$ See: https://primeminister.gr/2020/03/17/23593.

${ }^{6} \mathrm{We}$ decided to use both of the terms, insofar as the term epidemic dominated the public rhetoric in the beginning of the health crisis in March 2020 and was replaced later by the term pandemic.
} 


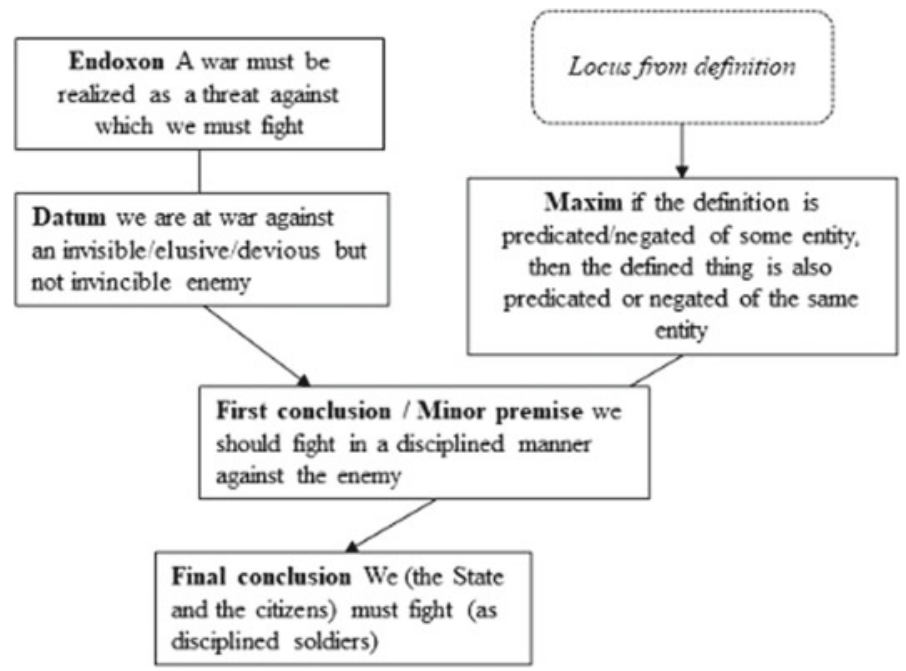

Fig. 11.2 The AMT quasi-Y reconstruction

Based on this specific metaphorical framing an argument is elaborated by the Aristotelian topos of the consequential (Rhetoric B23, 1399a) or the DHA topos of threat, realized in terms of the conditional "if there are specific dangers and threats, one should do something against them" (Reisigl \& Wodak, 2001: 77); that here could be labeled as the topos of epidemic/pandemic threat. On that basis, a plausible standpoint could emerge as follows: $1 \mathrm{We}$ (the State and the citizens) must fight (as disciplined soldiers) while the argument that supports it is: $1.1 \mathrm{We}$ are at war against an invisible/elusive/devious enemy. ${ }^{7}$ To secure this interpretation, we employ the AMT quasi-Y structure in an attempt to unveil the inference that binds the aforementioned coupling. Describing COVID-19 pandemic in terms of 'war' and therefore as a threat that needs to be addressed, the locus that governs the inferenceon the procedural-inferential component of the configuration-is the so-called locus from definition. A possible maxim that realizes this locus could be: if the definition is predicated/negated of some entity, then the defined thing is also predicated or negated of the same entity (see also Rigotti \& Greco, 2019: 302). On the materialcontextual component, an accepted endoxon could be: A war must be realized as a threat against which we must fight, while the datum that derives from the actual text is the following: we are at war against an invisible/elusive/devious but not invincible enemy. The first conclusion could be: we should fight in a disciplined manner against the enemy, paving the way to the final conclusion/standpoint: We (the State and the citizens) must fight (as disciplined soldiers) (see Fig. 11.2).

Moreover, what appears to be particularly important in extract 7 is Mitsotakis' effort to construct an inclusive 'We' group ('all of us-each one of us-'), comprised

\footnotetext{
${ }^{7}$ We adopt the pragma-dialectics (see Van Eemeren 2018) way to distinguish between standpoint (i.e. 1) and argument(s) (i.e. 1.1, 1.2 etc.).
} 
both from the 'government', himself and the citizens. In the unprecedented conditions of the COVID-19 pandemic, PM states that 'We' should 'prove to be disciplined soldiers' to achieve 'the victory' against the 'enemy'. In this sense, Mitsotakis discursively constructs a citizens-government coalition as the responsible social allience that could effectively combat the enemy through devotion and discipline. This involvement of citizens in leaders' strategic lines is further advanced by the other PMs.

In particular, in another part of his speech Macron states:

(8) I would like to repeat this with conviction tonight: [...] We must show solidarity and a sense of responsibility [...] Scientists have told us that this is our absolute priority. This is why, after having consulted and listened to the experts, I have decided to further strengthen the measures [...] Obviously, this evening, I am setting out new rules, we are imposing prohibitions and they will be enforced. But the best rule is the rule that you, as citizens, impose on yourselves. Once again, I am appealing to your sense of responsibility and solidarity.

What strikes our attention in this extract is the same construction of an in-group 'We' that is urged to prove solidarity and responsibility ('We must show solidarity and a sense of responsibility'). In this sense, Macron, portrays an ideal national unity ('We') based on the shared values of 'solidarity' and 'responsibility' as an effective means to overcome the pandemic. In other words, one could say that Macron's rhetoric here is led by the following conceptual schema: restrictions must be implemented as a sense of solidarity and responsibility toward the (French) nation. In this sense, Macron, combines the topos of governmental responsibility and the topos of citizen responsibility, which could be condensed into the conditional: "if citizens want to protect others and their beloved ones from the virus, then they have to demonstrate their social responsibility by following the measures". In this sense, Macron, represented the French authorities and citizens as a coalition-protectors of the nation and legitimized the restricting measures as a means of social and individual responsibility that are based on scientific data ('Scientists have told us') (see also Andone \& Loméli Hernández, 2022, this volume).

Furthermore, by employing the same rhetorical means and basing his argument on the synthesis of the two aforementioned topoi, Sanchez appealed to Spanish people duty. In particular, he noted:

(9) And all of us, of course, have a personal duty; strictly follow the indications of the experts and collaborate together to defeat the virus with the utmost responsibility and absolute social discipline [...]. The declaration of the State of Alarm allows the maximum mobilization of material resources to combat the virus [...]. Victory depends on each one of us, in our home, in our family, at work, in our neighborhood. Heroism also consists of washing hands, staying at home and protecting oneself, to protect all citizens.

Sanchez, indeed, pinpoints the 'personal duty' of each member of the in-group ('all of us', 'each one of us'). Similar to his counterparts, he urges the in-group to demonstrate 'responsibility' (Macron) and 'social discipline' (Mitsotakis) in order to achieve 
the 'victory'. He, moreover, mentions personal hygiene measures to highlight their importance against the 'enemy' and likened the exercise of personal hygiene practices and social distancing as 'heroism'.

Overall, this sense of citizens-authorities 'responsibility'/'discipline' and 'solidarity' is projected as the effective means by which the victory against the 'enemy' may be achieved. A standpoint-argument pair emerging here could be: 1 We need to rediscover a new responsibility/solidarity 1.1 Social responsibility/solidarity will be a key to defeat the virus/enemy. In AMT terms, this kind of reasoning is governed by a locus within the cause-effect argumentation, namely the locus from final/instrumental cause (see Rigotti \& Greco, 2019: 258), related to a maxim such as the following one: If something is a (necessary) means to reach an important goal, it should be employed. On the material-contextual component, an endoxon could be: social responsibly/solidarity is something good, and the datum that emerges from the extracts is: the disciplined in-group will provide victory (Mitsotakis), responsibility and solidarity is the priority according to the scientists (Macron), responsibility and discipline will help us defeat the virus (Sanchez). At the intersection of the two components, a first conclusion could be: our responsibility and solidarity can effectively combat the pandemic, while the final conclusion could be: We need to rediscover a new responsibility/solidarity to fight the pandemic (see Fig. 11.3).

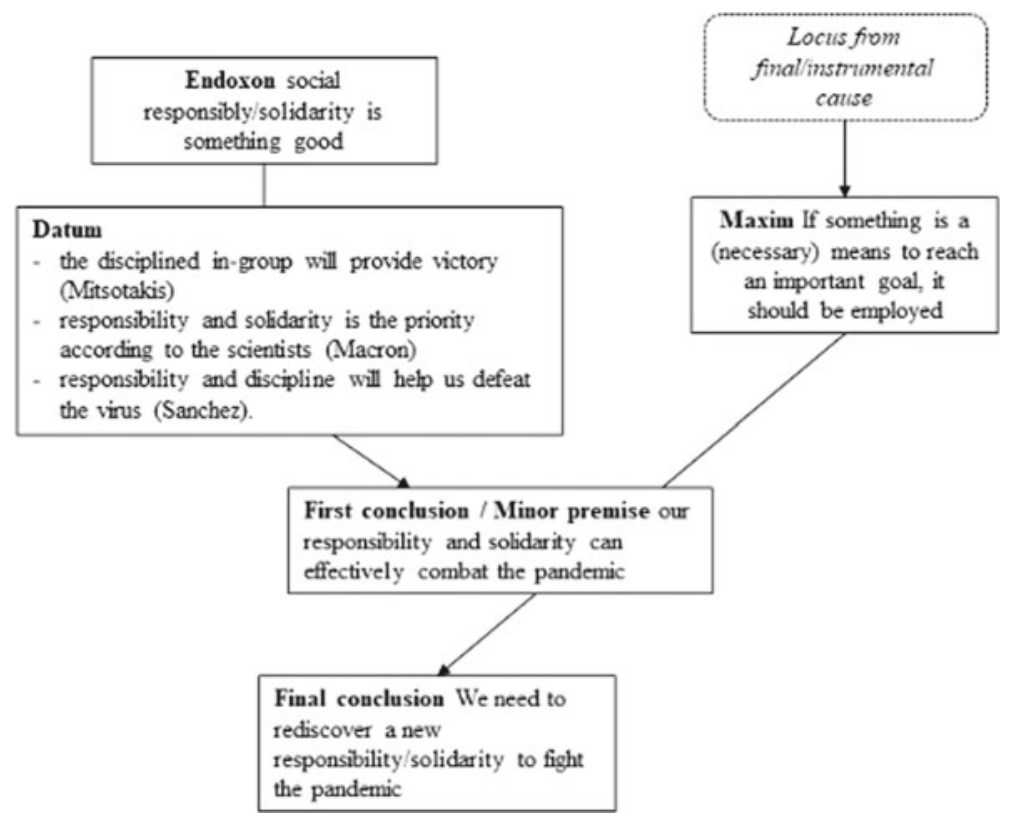

Fig. 11.3 The AMT quasi-Y reconstruction 
In a slightly different way, though capitalizing on the same conceptual ground of the emergency, while announcing a general lockdown in middle-March, Italian Premier, Giuseppe Conte, claimed $^{8}$ :

(10) Unfortunately, there is no time. [...] So, our habits should change. We must renounce something for the sake of Italy. [...] We must do it straight away and we will make it if all of us collaborate and adapt immediately to these more urgent norms. [...] If citizens' health as a public good is at risk, we are obliged to choose and impose sacrifices regarding other interests. The right decision today is to stay at home. Our future and Italy's future is in our hands and these hands should be responsible hands.

In his mandate to the nation, Conte constructs a sense of emergency through predicates that mention the lack of time 'Unfortunately, there is no time', 'We must do it straight away...'. In this sense he introduces the necessity for immediate countermeasures in the context of the pandemic. He constructs an in-group ('we', 'all of us', 'our hands') in an attempt to provide a sense of national unity (as his counterparts previously did) between his audience and himself and states that the action undertaken by the in-group is imperative because of the threat in public health ('citizens' health as a public good is at risk') and 'for the sake of Italy' and 'Our future and Italy's future'. Thus, the Italian leader attempts a legitimation of restrictive measures that need to be accepted because of the health emergency and on the conceptual basis that these serve national interests. The argumentative basis on which a claim could emerge is the DHA topos of (epidemic/pandemic) threat, which facilitates the necessity for countermeasures in front of a public danger/threat (see above). Therefore, a possible standpoint-argument pair could be: 1 We must underpin restrictive measures/sacrifices for Italy's shake/future 1.1 There is an emergency/public health is at risk. In AMT terms the inference that connects these elements is governed by the locus from termination and setting up (Rigotti \& Greco, 2019: 263), realized in terms of the maxim: if $\mathrm{X}$ is bad, then $\mathrm{X}$ must be terminated. The endoxon that is activated in this case could be: public health emergencies are something bad and the datum that relates to this endoxical view is: there is a public health emergency in Italy at the moment. Resulting from the interplay of the two components, a first conclusion could be: the health emergency in Italy is bad and thus should be terminated, leading to the final conclusion: We must underpin restrictive measures/sacrifices to terminate health emergency for Italy's shake/future (see Fig. 11.4).

The EU leaders pinpoint the existence of an irresponsible 'Other' that could jeopardize the national effort in the war against the enemy-pandemic. This becomes evident in Mitsotakis speech on March 22nd:

(11) I will not, however, allow a few careless ones undermine the safety of the majority. Because the few irresponsible can hurt thousands who are responsible. So, as hard times are approaching in the battle, we must close every backdoor to the evil.

\footnotetext{
${ }^{8}$ See: https://www.youtube.com/watch?v=dEqqpbwk7XI.
} 


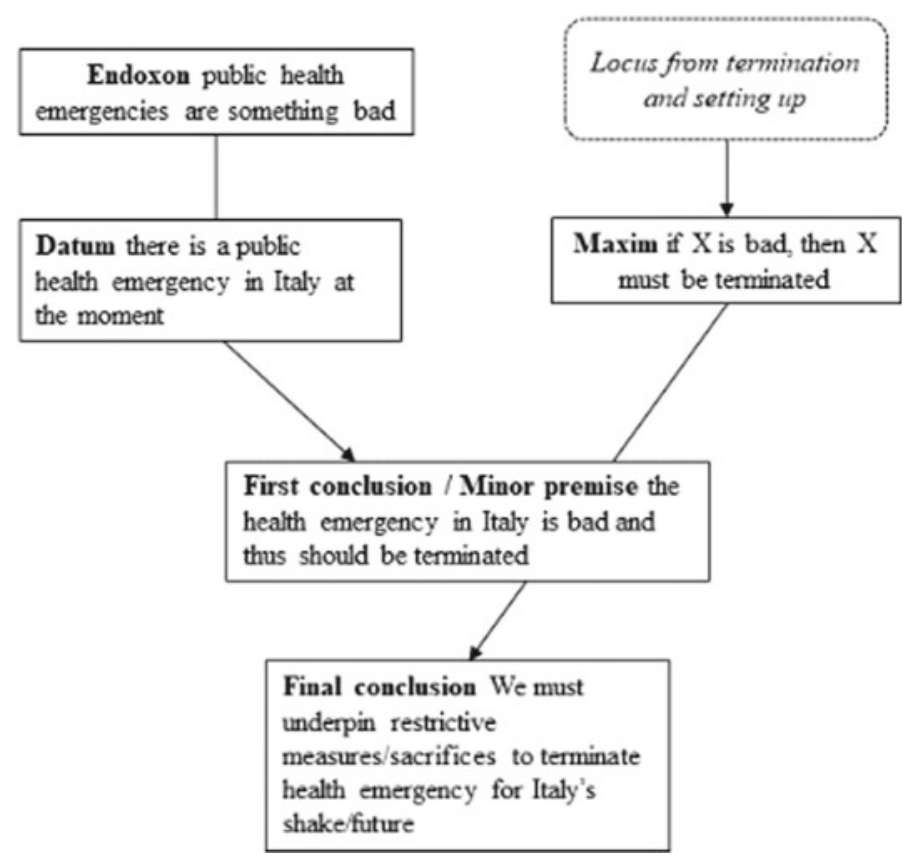

Fig. 11.4 The AMT quasi-Y reconstruction

In this case, Greek PM targets the 'few careless/irresponsible' that can 'hurt' the society as a whole. Thus, he creates an out-group of 'Others' that appears as an extra reason why the measures must be implemented. The same construction is evidenced in Macron's speech who also referred to the same social actors who do not follow the rules. In particular, he noticed:

(12) we also saw people gathering in parks, packed markets, restaurants and bars which did not respect the instructions to close [...] To all those who, by behaving like this, defied the instructions, I would very clearly like to say this evening: not only are you not protecting yourselves - and recent trends suggest that everyone is vulnerable to this virus, including the youngest in society - but you are failing to protect others.

Moreover, the Spanish PM personified those ('young people') who do not respect the measures. More specifically, he represented 'young people' as irresponsible via a generalization and requested their 'collaboration'. In particular, he mentioned:

(13) I would also like to address young people, who also have a decisive mission. It is true that due to their vitality they can feel sheltered from the most severe effects of the virus, but they can act as transmitters to other close people who are much more vulnerable. Their collaboration, the collaboration of young people, is decisive to cut infections and that is why they must limit contacts and maintain social distance. 
Along the lines of Greek PM's rhetoric, French and Spanish leaders developed a distinction between those who protect the nation and those who do not conform and 'fail to protect others' (Macron) since they 'can act as transmitters' (Sanchez). This kind of representation was previously implied also in Mitsotakis' speech (see extract 2) where he mentioned that 'the exercise of the civil liberty goes beyond the constitutional objectives and threatens the society' while favoring the implementation of restrictions based on some groups' irresponsibility ('when one's responsibility proves to be in deficit'). The reference to (ir)responsibility, once again, creates intertextual links among the different speeches, developing, in this sense, a discourse and argumentation against the irresponsible citizens. The overall argument is based again on the topos of citizen responsibility (see above).

All in all, citizens' responsibility appears to be among the effective means by which the different societies combat the pandemic, according to their leaders. The emerging standpoint-argument pair could be sketched along the following lines: 1 (Citizens') Responsibility will protect our society from the virus/enemy 1.1 Irresponsible behaviors can transmit the virus and negatively affect the vulnerable and the society. In AMT terms, this reasoning is, once more, governed by the locus from final/instrumental cause (Rigotti \& Greco, 2019: 258), related to a maxim such as the following one: If something is/is not a means to reach an important goal, it should be employed/avoided. On the material-contextual component, an endoxon could be: citizens must responsibly follow the rules, and the datum that emerges from the extracts is: being careless/irresponsible can harm the society (Mitsotakis), irresponsible individuals fail to protect others (Macron), irresponsible (young people) can be transmitters of the virus (Sanchez). At the intersection of the two components, a first conclusion could be: being irresponsible can negatively affect the spread of the pandemic, while the final conclusion could be: (Citizens') Responsibility will protect our society from the virus/enemy (see Fig. 11.5).

\subsection{Conclusion}

To sum up, our analysis reveals that leaders share similar lines of reasoning while attempting to impose restrictions in their countries and declare a state of emergency. Although they do not belong to the same political camps, their discourses seem to converge in this particular instance. Specifically, they employ the topos of (governmental) responsibility or the AMT locus from ontological implications while attempting to emphasize the positive portrayal of authorities that act in accordance to the constitutional rules and the common-well, and thus should be embraced by the public. They underline the emergency through the usage of war metaphors and the topos of (epidemic/pandemic) threat or the AMT locus from promising and warning before constructing the urgency of national unity, responsibility and solidarity as the means to overcome the pandemic on the basis of a combination of the DHA topoi of (governmental/citizen) responsibility and threat or the loci from final instrumental 


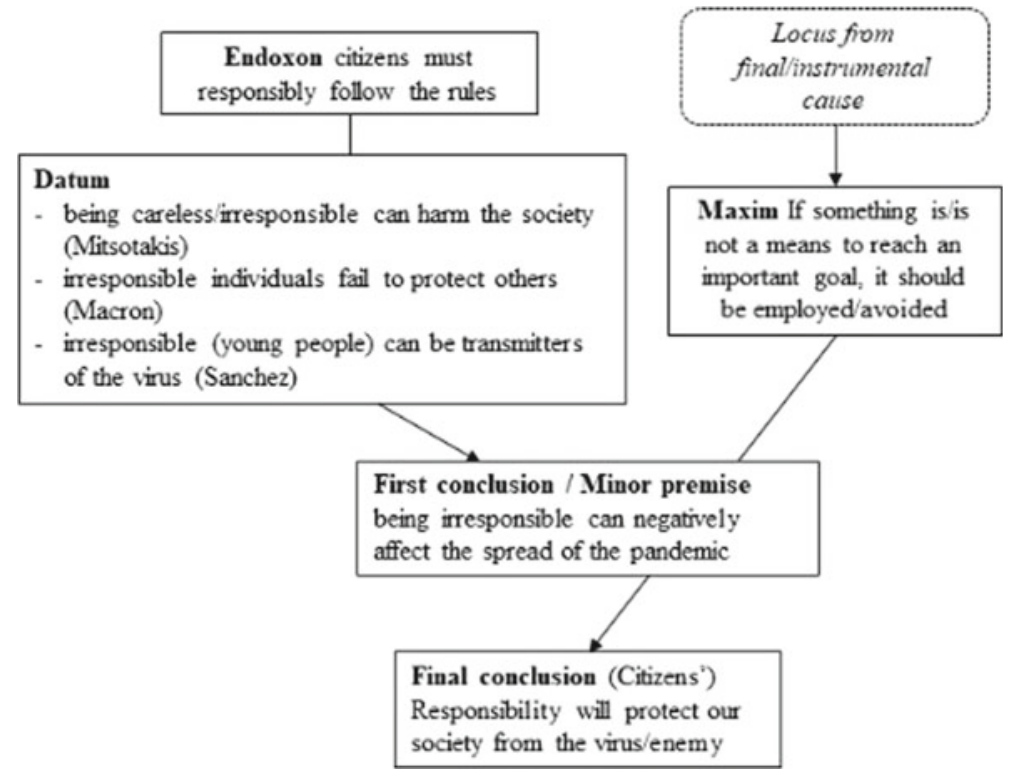

Fig. 11.5 The AMT quasi-Y reconstruction

cause and termination and setting up. In addition, they pinpoint citizen irresponsibility among the risks that could jeopardize the common fight against the enemy by employing the topos of (citizen) responsibility and the locus from final instrumental cause.

The comparative study that we provide here, at a first step apparently deals with a polylogical network that starts from different ideological orientations, in different places and with different audiences in Europe. In a second step, we observe that intertextual linkages permeate leaders' speeches that were linked to the recontextualization of similar constructions, while the political figures' argumentation that converges, made them "argumentative associates" (Mohammed, 2019) in the specific time span. On the basis of this overall convergence a standing standpoint could emerge along the following lines: Restrictive measures are necessary to address the pandemic adequately. In this vein a securitization perspective can be justified and further honed in a context of a state of emergency/exception such as the pandemic crisis. In an attempt to explain the state of exception and its function, Agamben (2003: 30) emphasized the concept of necessity. In our view necessity could be considered as an aporia of the discursive construction of the existential threat and the legitimation of emergency decrees on the name of security and peoples' safety. The war metaphors and the discursive construction of national responsibility cultivate the necessity of the restrict measures, and legitimize the political decisions by the usage of the above argumentation schemes (topoi/loci), and the emergence of the standing standpoint-outcome of the scrutinized argumentative polylogue. It is worth mentioning that PMs start from different ideological positionings (e.g. centrist, 
center-left, center-right), address different nations within the Southern EU crisis-hit context. Thus, they apparently create the premises for a complex, polylogical frame of communication/argumentation, where multiple players, from different positions advanced claims-arguments in different audiences. However, in light of the analysis, we can claim that their discourses ultimately seem to converge to the necessity for restrictive measures in order for the threat of the pandemic to be addressed effectively (see standing standpoint). In this sense, we could observe different ideological and political perspectives in different places in the EU coming together, creating and justifying, in the present case, a securitization viewpoint against a perceived threat-pandemic. We content that future research toward the same research avenue could shed light to the overall convergence of different political voices in the EU (e.g. center-right and center-left), which although historically belonging to different backgrounds, in times of crisis they seem to converge creating new hegemonic political views and narratives.

Moving beyond the function of the speech act and drawing on the elliptic narrow of the securitization theory (Wodak \& Boukala, 2014), we illustrate via this comparative study that the discursive construction of the COVID-19 threat can be further sustained by its underlying argumentation. Therefore, the proposed methodological approach can offer a critical perspective to the study of securitization in times of pandemic. This critical stance proves to be necessary in times of tectonic changes when political elites capitalize on crises/threat constructions, naturalize national (State-people) unity, to make socio-ideological antagonism vanish and confine democratic liberties and rights while declaring war to the perceived enemy.

The French President, Emmanuel Macron commented in the concluding lines of his address to the nation:

(14) Let us rise, individually and collectively...

I know, my dear compatriots, that I can count on you.

Long live the Republic, long live France!

An ending that reveals that COVID-19 challenged the civil rights and created a war climate. The fight against the pandemic required individual and collective attempts, as Macron noted, that justified emergency through securitization and on the basis of the discursive construction of the pandemic threat. Similar concluding remarks were utilized by the other political leaders and illustrate the diachronic value that war metaphors, nationalism and securitization have, insofar as politicians re-utilize them when they seek a way to invoke emergency strategies and ensure that they will be at peace with the citizens.

Acknowledgements This publication is based upon work from COST Action CA-17132, European Network for Argumentation and Public Policy Analysis (http://publicpolicyargument.eu), supported by COST (European Cooperation in Science and Technology). 


\section{References}

Aakhus, M., \& Lewiński, M. (2017). Advancing polylogical analysis of large-scale argumentation: Disagreement management in the Fracking controversy. Argumentation, 31(1), 179-207.

Agamben, G. (2003). State of exception. The University of Chicago Press.

Amossy, R. (2002). How to do things with doxa: Toward an analysis of argumentation in discourse. Poetics Today, 23(3), 465-487.

Amossy, R. (2009). Argumentation in discourse: A socio-discursive approach to arguments. Informal Logic, 29(3), 252-267.

Amossy, R. (2009). The new rhetoric's inheritance. Argumentation and Discourse Analysis. Argumentation, 23, 313-324.

Andone, C., \& Lomelí Hernández, J. A. (2022, this volume). On arguments from ignorance in policy-making. In S. Oswald, M. Lewiński, S. Greco, \& S. Villata (Eds.), The pandemic of argumentation (pp. 101-120). Springer. https://doi.org/10.1007/978-3-030-91017-4_6

Austin, J. L. (1962). How to do things with words (2nd ed.). Harvard University Press.

Boukala, S. (2016). Rethinking topos in the discourse historical approach: Endoxon seeking and argumentation in Greek media discourses on 'Islamist terrorism.' Discourse Studies, 18(3), 249268.

Boukala, S. (2019). European identity and the representation of Islam in the mainstream press: Argumentation and media discourse. Palgrave Macmillan.

Buzan, B., Wæver, O., \& de Wilde, J. (1998). Security: A new framework for analysis. Lynne Rienner.

Castro Seixas, E. (2021). War metaphors in political communication on COVID-19. Frontiers in Sociology, 5, 583680. https://doi.org/10.3389/fsoc.2020.583680

Fairclough, N. (2003). Analysing discourse: Textual analysis for social research. Routledge.

Fairclough, I., \& Fairclough, N. (2012). Political discourse analysis: A method for advanced students. Routledge.

Herman, T., \& Serafis, D. (2019). Emotions, argumentation, and argumentativity: Insights from an analysis of newspaper headlines in the context of the Greek crisis. Informal Logic, 39(4), 373-400.

Kelsey, D., Mueller, F., Whittle, A., \& KhosraviNik, M. (Eds.). (2016). Financial crisis and austerity: Interdisciplinary concerns in critical discourse studies. [Special issue] Critical Discourse Studies, 13(1).

Kristeva, J. (1980). Desire in language: A semiotic approach to literature and art (trans. L.S. Roudiez). Blackwell.

Krzyżanowski, M. Triandafyllidou, A. and Wodak, R. (2018). (Eds). The mediatization and politicization of the refugee crisis in Europe. [Special issue] Journal of Immigrant \& Refugee Studies $16(1-2)$

Lewiński, M., \& Aakhus, M. (2014). Argumentative polylogues in a dialectical framework: A methodological inquiry. Argumentation, 28(2), 161-185.

McDonald, M. (2008). Securitization and the construction of security. European Journal of International Relations, 14, 563-587.

Mohammed, D. (2019). Standing standpoints and argumentative associates: What is at stake in a public political argument? Argumentation, 33, 307-322.

Möller, F. (2007). Photographic interventions in post-9/11 security policy. Security Dialogue, 38(2), 179-196.

Reisigl, M. (2014). Argumentation analysis and the discourse-historical approach: A methodological framework. In C. Hart \& P. Cap (Eds.), Contemporary Critical Discourse Studies (pp. 67-96). Bloomsbury.

Reisigl, M., \& Wodak, R. (2001). Discourse and discrimination: Rhetorics of racism and antisemitism. Routledge.

Reisigl, M., \& Wodak, R. (2016). The discourse-historical approach (DHA). In R. Wodak \& M. Meyer (Eds.), Methods of critical discourse studies (3rd ed., pp. 23-61). Sage. 
Rheindorf, M. (2019). Revisiting the toolbox of discourse studies. Palgrave.

Rigotti, E., \& Greco, S. (2019). Inference in argumentation: A topics-based approach to argument schemes. Springer.

Serafis, D., \& Herman, T. (2018). Media discourse and pathos: Sketching a critical and integrationist approach-Greek and French headlines before the Greek referendum of 2015. Social Semiotics, 28(2), 184-200.

Serafis, D., Greco, S., Pollaroli, C., \& Jermini-Martinez Soria, C. (2020). Towards an integrated argumentative approach to multimodal critical discourse analysis: Evidence from the portrayal of refugees and immigrants in Greek newspapers. Critical Discourse Studies, 17(5), 545-565.

Serafis, D., Raimondo, C., Assimakopoulos, S., Greco, S., \& Rocci, A. (in press). Argumentative dynamics in representations of migrants and refugees: Evidence from the Italian press during the 'refugee crisis'. Discourse \& Communication.

Stråth. B., \& Wodak, R. (2009). Europe-Discourse-Politics-Media-History: Constructing 'crises'?. In A. Triandafyllidou R. Wodak, \& M. Krzyżanowski (Eds.), The European public sphere and the media: Europe in crisis (pp. 15-33). Palgrave Macmillan.

Williams, M. C. (2003). Words, images, enemies: Securitization and international politics. International Studies Quarterly, 47(4), 511-532.

Wodak, R., \& Meyer, M. (Eds.). (2016). Methods of critical discourse studies (3rd ed.). Sage.

Wodak, R., \& Boukala, S. (2014). Talking about solidarity and security in the age of crisis: The revival of nationalism and protectionism in the European Union-A Discourse-Historical Approach. In C. Carta \& J. Morin (Eds.), EU foreign policy through the lens of discourse analysis making sense of diversity (pp. 171-190). Ashgate.

Wodak, R., \& Fairclough, N. (2010). Recontextualizing European higher education policies: The cases of Austria and Romania. Critical Discourse Studies, 7(1), 19-40.

Wodak, R. (in press). Crisis communication and crisis management during COVID-19. Global Discourse.

Open Access This chapter is licensed under the terms of the Creative Commons Attribution 4.0 International License (http://creativecommons.org/licenses/by/4.0/), which permits use, sharing, adaptation, distribution and reproduction in any medium or format, as long as you give appropriate credit to the original author(s) and the source, provide a link to the Creative Commons license and indicate if changes were made.

The images or other third party material in this chapter are included in the chapter's Creative Commons license, unless indicated otherwise in a credit line to the material. If material is not included in the chapter's Creative Commons license and your intended use is not permitted by statutory regulation or exceeds the permitted use, you will need to obtain permission directly from the copyright holder.

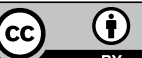

